\title{
Deposition of Hydroxyapatite on Silica Made from Rice Husk Ash to Produce the Powder Component of Calcium Phosphate Cement
}

\author{
Tri Windarti ${ }^{12^{*}}$, Widjijono ${ }^{3}$, and Nuryono ${ }^{2 * *}$ \\ ${ }^{1}$ Department of Chemistry, Faculty of Science and Mathematics, Universitas Diponegoro, \\ Jl. Prof. Soedharto SH, Tembalang, Semarang 50275, Indonesia \\ ${ }^{2}$ Department of Chemistry, Faculty of Mathematics and Natural Sciences, Universitas Gadjah Mada, \\ Sekip Utara, Yogyakarta 55281, Indonesia \\ ${ }^{3}$ Department of Dental Biomaterials, Faculty of Dentistry, Universitas Gadjah Mada, \\ Jl. Denta 1, Sekip Utara, Yogyakarta 55281, Indonesia
}

\author{
* Corresponding author: \\ email: tri.windarti@lecturer.undip.ac.id; \\ nuryono_mipa@ugm.ac.id ${ }^{* *}$ \\ Received: July 16, 2020 \\ Accepted: September 10, 2020 \\ DOI: $10.22146 /$ ijc. 57900
}

\begin{abstract}
Hydroxyapatite (HA) has been deposited on silica $\left(\mathrm{SiO}_{2}\right)$ particles to produce $\mathrm{HA}-\mathrm{SiO}_{2}$ composite that will be used as the powder component of calcium phosphate cement. HA was expected to be on the composite surface to maintain its bioactivity. $\mathrm{SiO}_{2}$ was made by the sol-gel method, in which silicate solution was extracted from rice husk ash with $\mathrm{NaOH}$ solution. Deposition of $\mathrm{HA}$ on $\mathrm{SiO}_{2}$ was carried out by wet chemical deposition method at various $\mathrm{Ca} / \mathrm{Si}$ molar ratio (in a range of 5-25) followed by calcination at $600{ }^{\circ} \mathrm{C}$ for $2 \mathrm{~h}$. Results showed that $\mathrm{HA}$ was successfully deposited on $\mathrm{SiO}_{2}$ particles. The cell parameters of the HA crystals were slightly distorted by the presence of $\mathrm{SiO}_{2}$ and $\mathrm{HA}$ in the composite had a bigger cell volume than pure HA. The crystallite size of HA in the composites increased with the increase of the Ca/Si ratio but the values were smaller than pure $\mathrm{HA}$. $\mathrm{SiO}_{2}$ acted as a morphology directing agent. At low $\mathrm{Ca} / \mathrm{Si}$ ratio, the $\mathrm{HA}-\mathrm{SiO}_{2}$ particles were in a form of short rod-like particles with sizes of $<50 \mathrm{~nm}$, while at high $\mathrm{Ca} / \mathrm{Si}$ ratio, a mixture of short and long rod-like particles with the size of $<100 \mathrm{~nm}$ was obtained. The zeta potential of composites was almost similar to pure $\mathrm{HA}$. These properties indicated that $\mathrm{HA}-\mathrm{SiO}_{2}$ composites support the bioactivity of injectable calcium phosphate cement.
\end{abstract}

Keywords: hydroxyapatite; silica; rice husk ash; calcium phosphate cement

\section{- INTRODUCTION}

Calcium phosphate cement (CPC) has been widely developed due to its ability to induce bone formation and vascularization. Injectable CPC consists of powder and liquid components. Calcium phosphate and its mixture are common materials used as the powder component and an aqueous solution of calcium or phosphate ion is used as the liquid component. The mixture of the two components produces a paste that can be injected into a damaged bone. Inside the body, the paste may harden to result in a temporary bone substitute [1-3]. Additives are often added to improve the property of CPC. One of the most studied additives with a strong influence on the property of CPC is siliceous solids like silica $\left(\mathrm{SiO}_{2}\right)$ and calcium silicate $\left(\mathrm{CaSiO}_{3}\right)$ [4-9]. For instance, the addition of $5 \%$ fibrous $\mathrm{CaSiO}_{3}$ into $\mathrm{CPC}$ increased the compressive strength of the resulting cement by $250 \%$ (from 14.5 MPa to 50.4 MPa) [10]. The setting reaction of CPC with silica precursor produced a porous composite with pore diameters in the range of 1-10 nm [11]. Moreover, CPC-silica composite was found to have an ability to improve cell adhesion and proliferation as well as stimulating osteogenic differentiation [12-14].

To adjust the contribution of silica additives to the improvement of CPC's properties, modification of the powder component, typically calcium phosphate in the form of hydroxyapatite $\left[\mathrm{HA},\left(\mathrm{Ca}_{10}\left(\mathrm{PO}_{4}\right)_{6}(\mathrm{OH})_{2}\right]\right.$, has

Tri Windarti et al. 
been intensively studied. Synthetic HA is known as a good bone substitute due to its properties such as being osteoconductive, biocompatible, and bioactive [15-18]. Normally, modification of $\mathrm{HA}$ with $\mathrm{SiO}_{2}$ that is performed under alkaline conditions, produce composites in which silica covers the HA particles [19]. Moreover, under high $\mathrm{Ca} / \mathrm{P}$ reactant ratios, which are usually used to produce $\mathrm{HA}, \mathrm{CaO}$ is formed as a secondary product. The presence of $\mathrm{CaO}$ decreases the composite surface area. This is undesirable for the powder component of CPC because the presence of silica on the composite surface and the reduced surface area of the composite reduce the bioactivity of HA. On the other hand, a study about $\mathrm{HA}-\mathrm{SiO}_{2}$ morphology showed that the composite was built in such a way that silica interacted with the $a$-plane of HA and then HA crystals grew along the c-axis and produced needle-like particles [20]. However, the formation of such shaped particles should be avoided for injectable CPC, because it reduces the injectability of the paste material.

Silica is silicon dioxide $\left(\mathrm{SiO}_{2}\right)$, which forms a threedimensional framework through siloxane ( $\mathrm{Si}-\mathrm{O}-\mathrm{Si}$ ) bonds to build an amorphous and porous structure. Silica material has important properties such as soluble in water, chemically inert, thermally stable, and compatible for biomedical applications [21-23]. One of the sources of silica in nature is rice husk ash, in which rice is a very abundant and renewable commodity. Simple extraction of rice husk ash with $\mathrm{NaOH}$ produces silica with the same chemical and physical properties as commercial silica [24]. Silica from rice husk ash has a high purity and is a nano-sized material, and has also been applied for several industries such as pharmaceuticals and cosmetics [22].

In this study, the modification of HA with silica was conducted by depositing $\mathrm{HA}$ on $\mathrm{SiO}_{2}$ to produce nanosized $\mathrm{HA}-\mathrm{SiO}_{2}$ composites. Owing to such structure, it is expected that HA in the composite directly interacts with living bone tissue when the composite is used as CPC. In addition, composite particles are expected to have a shape that is suitable to improve the cement's injectability. This study was based on a previous work regarding in situ synthesis of mesoporous silica MCM-41/HA composite [23]. The research found that the arrangement of HA and
$\mathrm{SiO}_{2}$ in the composite depended on the aging time. At shorter aging times, $\mathrm{SiO}_{2}$ was found on the composite surface while at longer aging times, the composite was covered by HA. It can be concluded that, thermodynamically, during the synthesis process, $\mathrm{SiO}_{2}$ and HA particles tried to get the lowest free energy. At first, silica was well dispersed in the reactant solution and the HA crystal was built on the silica surface by silanol-Ca interaction. The HA particles tended to interact with each other, which resulted in HA being inside of the composite and $\mathrm{SiO}_{2}$ on the surface. With the increase of aging time, $\mathrm{SiO}_{2}$ was then covered with $\mathrm{HA}$ that was built next from the reactant solution. That is why the position of $\mathrm{SiO}_{2}$ and $\mathrm{HA}$ in the composite surface is seen to have changed during aging time. In the current work, these phenomena are predicted to occur when synthesis of the $\mathrm{HA}-\mathrm{SiO}_{2}$ composite is conducted at various $\mathrm{Ca} / \mathrm{Si}$ reactant ratio. The silica was synthesized from rice husk ash by the sol-gel method and the formation of $\mathrm{HA}-\mathrm{SiO}_{2}$ composite was done by the wet chemical deposition method. The chemical structure, surface properties, and zeta potential of the $\mathrm{HA}-\mathrm{SiO}_{2}$ composite were studied according to the properties needed for the powder component of CPC.

\section{- EXPERIMENTAL SECTION}

\section{Materials}

Rice husk as the silica source was collected from a rice mill in Karanganyar, Central Java, Indonesia. Chemicals including $\mathrm{NaOH}$ (Merck), $\mathrm{HCl}$ (Merck), and deionized water were used in the silica preparation. For the synthesis of the $\mathrm{HA}-\mathrm{SiO}_{2}$ composite, $\mathrm{Ca}\left(\mathrm{NO}_{3}\right)_{2} \cdot 4 \mathrm{H}_{2} \mathrm{O}$ (Merck) and $\mathrm{KH}_{2} \mathrm{PO}_{4}$ (Merck) were used as $\mathrm{Ca}$ and $\mathrm{P}$ precursors, respectively. Double distilled water (Ikapharmindo Putramas) and $\mathrm{NH}_{4} \mathrm{OH} 32 \%$ (Merck) were used as solvent and for $\mathrm{pH}$ adjustment, respectively. All chemicals were in analytical grade and used without further purification.

\section{Instrumentation}

The functional groups of the samples were analyzed with Fourier Transform Infrared (FTIR) spectrophotometer (Shimadzu) through a $\mathrm{KBr}$ pellet 
method at a wavenumber range of $400-4000 \mathrm{~cm}^{-1}$ (Scan step wavenumber of $\left.7.715264 \mathrm{~cm}^{-1}\right)$. The crystal structure was characterized by X-Ray Diffraction (XRD) (Rigaku type Miniflex600) that was equipped with monochromatic $\mathrm{Cu} \mathrm{Ka}$ radiation, operated at $40 \mathrm{~kW}(\lambda=1.54 \AA)$ and scanned for $2^{\circ} \leq 2 \theta \leq 90^{\circ}$ at a scan step degree of $0.02^{\circ}$. XRD data was fitted by using the Origin software. Cell parameters were calculated with mathematic equations based on hexagonal structure and Bragg's law. Crystallite size was calculated by Scherrer equation. Surface morphology, element distribution, shape and size of particles on surfaces were observed using Scanning Electron Microscope-Energy Dispersive Spectroscopy (SEM-EDS) (Hitachi type SU3500) and Hitachi MC1000 sputter ion for sample coating with gold in a thickness of $1 \mathrm{~nm}$. The shape and size of the particles were observed with Tunneling Electron Microscope (TEM) (JEOL type JEM-1400) by using ethanol as the dispersant. Zetaziser Nano form Malvern was used to record zeta potential value. The measurement was conducted at room temperature at $\mathrm{pH} 7$ for samples that were dispersed in water and $1 \%(\mathrm{v} / \mathrm{v})$ Tween 80 .

\section{Procedure}

\section{Preparation of silica}

Rice husk was burned in fire to produce charcoal. The charcoal was then calcined at $700{ }^{\circ} \mathrm{C}$ for $4 \mathrm{~h}$ to obtain rice husk ash (RHA). The RHA sample was crushed and sieved with a 200 mesh sieve to obtain RHA powder. Afterwards, about $10 \mathrm{~g}$ of RHA powder was mixed with $60 \mathrm{~mL}$ of $2 \mathrm{M} \mathrm{NaOH}$ solution. The mixture was heated at $65{ }^{\circ} \mathrm{C}$ and stirred for $1 \mathrm{~h}$ to obtain a suspension. The suspension was then filtered, and the residue was mixed again for the second time with $30 \mathrm{~mL}$ of $2 \mathrm{M} \mathrm{NaOH}$ solution. The obtained filtrate was added with $\mathrm{HCl} 25 \%$ dropwise to reach $\mathrm{pH} 7.0$ or until a white gel was formed. The obtained gel was washed with deionized water by sonication for $1 \mathrm{~h}$ to get a white residue and then the white residue was heated at $400^{\circ} \mathrm{C}$ for $4 \mathrm{~h}$. The product was later crushed and sieved with a 200 mesh sieve and the obtained powders were considered as silica.

\section{Deposition of hydroxyapatite on silica}

A certain weight of $\mathrm{Ca}\left(\mathrm{NO}_{3}\right)_{2} \cdot 4 \mathrm{H}_{2} \mathrm{O}$ and silica were
Table 1. The composition of precursors for the preparation of $\mathrm{HA}-\mathrm{SiO}_{2}$ composites at various $\mathrm{Ca} / \mathrm{Si} \mathrm{R}_{(\mathrm{R})}$ molar ratios ${ }^{*}$

\begin{tabular}{cccc}
\hline Sample code & $\mathrm{Ca}\left(\mathrm{NO}_{3}\right)_{2} \cdot 4 \mathrm{H}_{2} \mathrm{O}(\mathrm{g})$ & $\mathrm{KH}_{2} \mathrm{PO}_{4}(\mathrm{~g})$ & $\mathrm{Ca} / \mathrm{Si}_{(\mathrm{R})}$ \\
\hline $\mathrm{A} 0$ & 19.719 & 6.804 & - \\
$\mathrm{A} 1$ & 4.912 & 1.699 & 5 \\
$\mathrm{~A} 2$ & 9.824 & 3.397 & 10 \\
$\mathrm{~A} 3$ & 14.736 & 5.095 & 15 \\
$\mathrm{~A} 4$ & 19.647 & 6.793 & 20 \\
$\mathrm{~A} 5$ & 24.560 & 8.491 & 25 \\
\hline
\end{tabular}

${ }^{*} \mathrm{Ca} / \mathrm{P}$ ratio and $\mathrm{SiO}_{2}$ content were kept constant at 1.67 and $0.25 \mathrm{~g}$

mixed with double distilled water to produce $50 \mathrm{~mL}$ of solution I. Fifty $\mathrm{mL}$ of solution II was prepared by dissolving a certain weight of $\mathrm{KH}_{2} \mathrm{PO}_{4}$ in double-distilled water. Solution II was then slowly added to solution I with gentle stirring. Afterwards, about $15 \mathrm{~mL}$ of $\mathrm{NH}_{4} \mathrm{OH}$ $32 \%$ was added into the mixture to reach $\mathrm{pH}>9$. The stirring process was continued for $1 \mathrm{~h}$ and then the mixture was kept at room temperature for $24 \mathrm{~h}$. The formed precipitate was washed with $2 \mathrm{~L}$ of double distilled water and dried in an electric oven at $50{ }^{\circ} \mathrm{C}$ for $48 \mathrm{~h}$ to obtain a white powder. The product was called as-precipitate powder. The as-precipitate powder was calcined in an electric furnace at $600{ }^{\circ} \mathrm{C}$ for $2 \mathrm{~h}$ at air atmosphere to obtain the $\mathrm{HA}-\mathrm{SiO}_{2}$ composite (calcined powder). The composition of the precursors and the sample codes are presented in Table 1.

\section{- RESULTS AND DISCUSSION}

The transformation of the chemical and crystal structure of the products at various $\mathrm{Ca} / \mathrm{Si}$ reactant molar ratio $\left(\mathrm{Ca} / \mathrm{Si}_{(\mathrm{R})}\right)$ were studied for the as-precipitate and calcined powder. Meanwhile, the surface properties and zeta potential were studied for the calcined powder.

\section{FTIR Analysis}

Fig. 1 shows the FTIR spectra of $\mathrm{SiO}_{2}$ and the HA$\mathrm{SiO}_{2}$ composite. For the $\mathrm{SiO}_{2}$ spectrum, characteristic peaks of $\mathrm{SiO}_{2}$ appeared at 1100,805 and $466 \mathrm{~cm}^{-1}$ that are attributed to the antisymmetric stretching vibration of $\mathrm{Si}-\mathrm{O}-\mathrm{Si}$, symmetric vibration of $\mathrm{Si}-\mathrm{O}-\mathrm{Si}$ and bending vibration of $\mathrm{Si}-\mathrm{O}-\mathrm{Si}$, respectively. A broad peak around $3500 \mathrm{~cm}^{-1}$ is attributed to the vibration of the silanol group. For the as-precipitate powder, the antisymmetric 

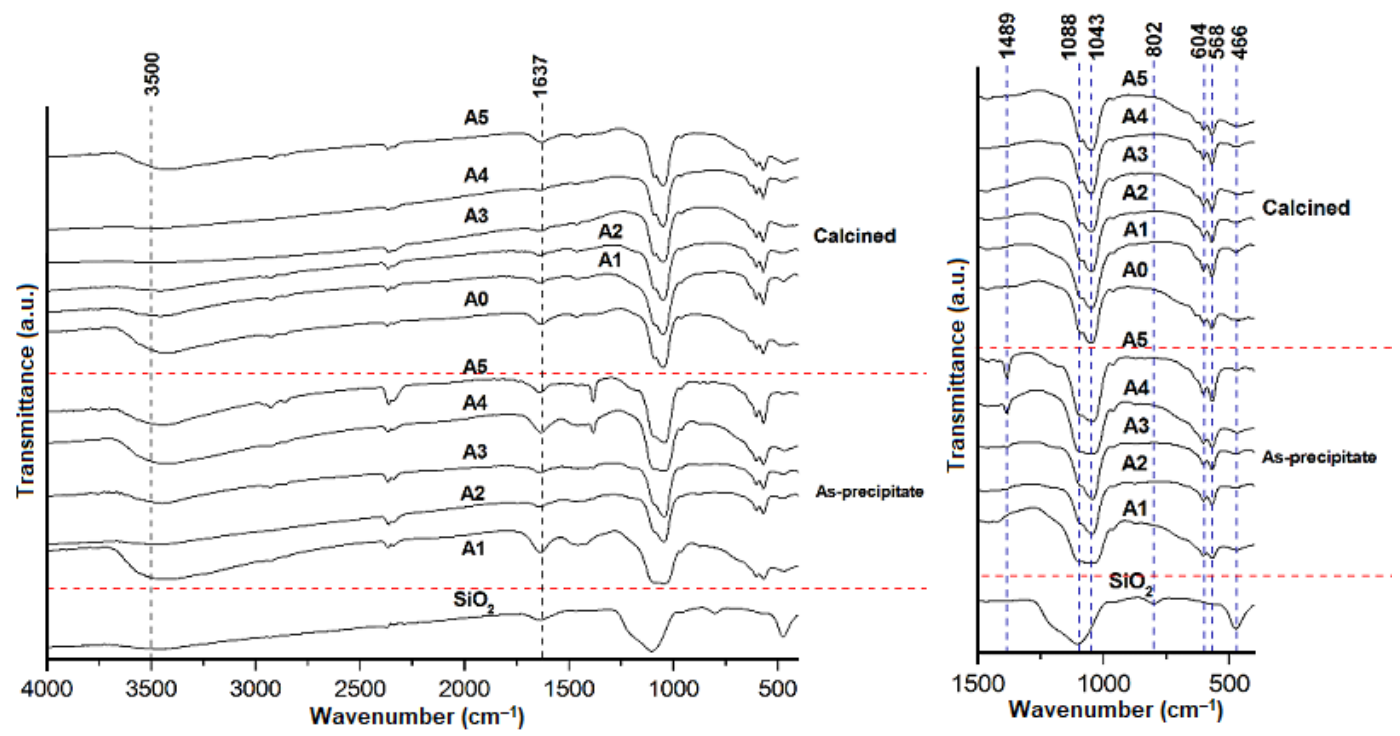

Fig 1. FTIR spectra of $\mathrm{SiO}_{2}$ and $\mathrm{HA}-\mathrm{SiO}_{2}$ composites

stretching vibration of $\mathrm{Si}-\mathrm{O}-\mathrm{Si}$ overlapped with the peak of the asymmetric stretching vibration of $\mathrm{PO}_{4}{ }^{3-}$ at $1088 \mathrm{~cm}^{-1}$. The peak of the bending vibration of $\mathrm{Si}-\mathrm{O}-\mathrm{Si}$ at around $466 \mathrm{~cm}^{-1}$ decreased significantly and the peak of the symmetric vibration of $\mathrm{Si}-\mathrm{O}-\mathrm{Si}$ at $805 \mathrm{~cm}^{-1}$ disappeared. This phenomenon has been explained by a literature, which stated that introducing $\mathrm{Ca}^{2+}$ ions into a $\mathrm{SiO}_{2}$ network may damage some $\mathrm{Si}-\mathrm{O}-\mathrm{Si}$ bonds to form $\mathrm{Si}-\mathrm{O}-\mathrm{Ca}-\mathrm{O}-\mathrm{Si}$ groups [25].

During the deposition process, the silanol groups in $\mathrm{SiO}_{2}$ released $\mathrm{H}^{+}$due to the alkaline condition produced by the $\mathrm{Si}-\mathrm{O}^{-}$site. The $\mathrm{Si}-\mathrm{O}^{-}$site then interacted with $\mathrm{Ca}^{2+}$ to form $\mathrm{Si}-\mathrm{O}-\mathrm{Ca}^{+}$which interacted further with $\mathrm{PO}_{4}{ }^{3-}$ and another $\mathrm{Ca}^{2+}$ until HA crystal seeds were formed. The crystal seed grew continuously on the $\mathrm{SiO}_{2}$ surface in 3 dimensions. The tetrahedral symmetry of the $\mathrm{PO}_{4}{ }^{3-}$ group such as the asymmetric stretching $\left(\mathrm{v}_{3}\right)$ appeared as sharp peaks at 1088 and $1043 \mathrm{~cm}^{-1}$ and the asymmetric deformation $\left(\mathrm{v}_{4}\right)$ appeared at 568 and $604 \mathrm{~cm}^{-1}$ [26-27]. A wide peak around $3500 \mathrm{~cm}^{-1}$ indicated the presence of stretching $\mathrm{O}-\mathrm{H}$ groups with hydrogen bonds of $\mathrm{HA}$ or absorbed $\mathrm{H}_{2} \mathrm{O}$. The presence of absorbed $\mathrm{H}_{2} \mathrm{O}$ is proven by a peak at $1637 \mathrm{~cm}^{-1}$. $\mathrm{CO}_{3}{ }^{2-}$ groups that substitute $\mathrm{PO}_{4}{ }^{3-}$ site appeared at $1489 \mathrm{~cm}^{-1}$ [28-29]. The spectra of calcined powder A0-A5 looks similar to the as-precipitate spectra but with sharper peaks. Calcination of the as-precipitate powder at $600{ }^{\circ} \mathrm{C}$ for $2 \mathrm{~h}$ caused molecules arrangement and the release of small molecules such as $\mathrm{CO}_{2}$ and $\mathrm{H}_{2} \mathrm{O}$, causing the $\mathrm{CO}_{3}{ }^{2-}$ peak to disappear, and the $\mathrm{H}_{2} \mathrm{O}$ peak became shorter.

\section{XRD Analysis}

Crystal analysis based on XRD patterns is shown in Fig. 2. The characteristic peak of $\mathrm{SiO}_{2}$ appeared as a broad peak at $2 \theta=22^{\circ}$. This peak disappeared when $\mathrm{SiO}_{2}$ was composited with $\mathrm{HA}$, due to the strong interaction of silica - HA [30]. For all as-precipitate powder, HA with low crystallinity was formed in the composites. The intensity of the peaks and sharpness increased with the increase of the $\mathrm{Ca} / \mathrm{Si}$ molar ratio of the reactants $\left(\mathrm{Ca} / \mathrm{Si}_{(\mathrm{R})}\right)$. The peaks of the calcined powder were sharper than the as-precipitate powder. These peak patterns confirmed that the composites contained HA in hexagonal crystal lattice according to JCPDS card no 090432. The crystal cell parameters of the standard were $\mathrm{a}=\mathrm{b}=0.9418 \mathrm{~nm} \mathrm{c}=0.6884 \mathrm{~nm}, \alpha=\beta=90^{\circ} \gamma=120^{\circ}$ and cell volume $=1.586 \mathrm{~nm}^{3}$. Broad peaks of HA that appeared at $2 \theta$ of around $25,31,32,33,34,40,47$ and $49^{\circ}$ are attributed to the crystal plane of (002), (211), (112), (300), (202), (212), (222), and (213), respectively. The low crystallinity of HA is desirable for biomaterial because it produces high bioactivity [31]. The effect of the $\mathrm{Ca} / \mathrm{Si}_{(\mathrm{R})}$ molar ratio to the HA crystal formation can be seen from the increase of peak intensity and the sharpening of the 

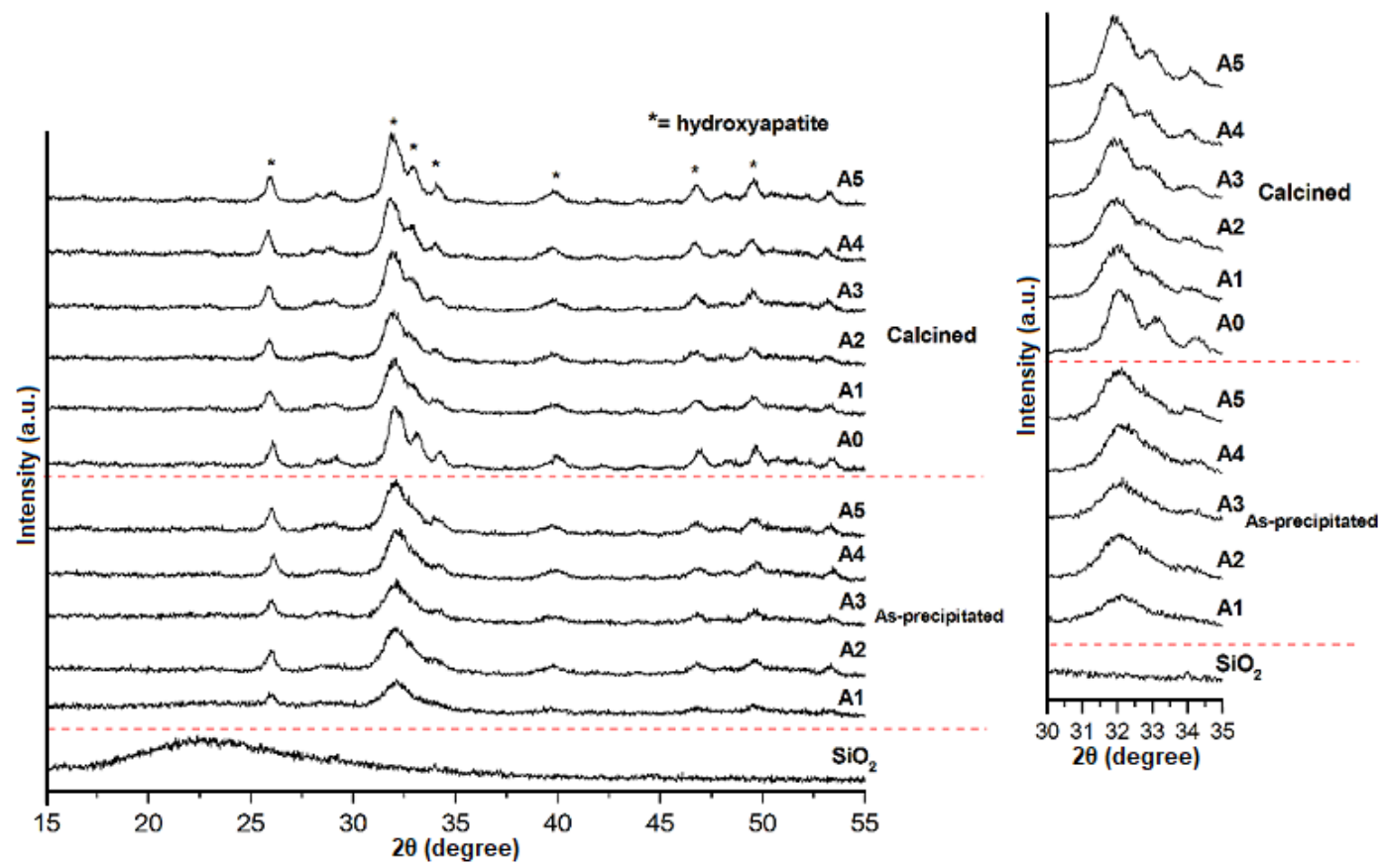

Fig 2. XRD patterns of $\mathrm{SiO}_{2}$ and $\mathrm{HA}-\mathrm{SiO}_{2}$ composites

peak shape as the $\mathrm{Ca} / \mathrm{Si}(\mathrm{R})$ ratio increases (Fig 2. inset). At high $\mathrm{Ca} / \mathrm{Si}_{(\mathrm{R})}$ molar ratio, the effect of silica on the formation of HA was not significant.

From the diffraction data that were fitted with Origin, the $2 \theta$ position and FWHM of every single peaks was able to be determined. The d-spacing that was calculated using Brag's law and the information of miller indices from JCPDS data was used to determine the and c parameters of HA crystal in A0-A5 samples. Also, the Scherrer equation was used to calculate the crystallite size. The cell parameters and crystallite size of HA in A0-A5 samples are shown in Table 2. The a value for all samples was almost the same. Meanwhile, the $c$ value, as well as the cell volume of HA in the composites, were larger than pure $\mathrm{HA}$ but those values were fluctuated to $\mathrm{Ca} / \mathrm{Si}_{(\mathrm{R})}$. The formation of HA crystal was slightly distorted by the presence of $\mathrm{SiO}_{2}$. The crystallite size of HA in A1-A5 samples was in the range of $7.557 \pm 0.164-9.581 \pm 0.144$ $\mathrm{nm}$ which was lower than pure HA $(12.788 \pm 0.450 \mathrm{~nm})$. The crystallite size increased with the increase of $\mathrm{Ca} / \mathrm{Si}_{(\mathrm{R})}$. The $\mathrm{HA}-\mathrm{SiO}_{2}$ composite is predicted to have a higher bioactivity than pure HA due to its higher volume and lower crystallite size. All parameters of the HA cell products were lower than the HA standard in JCPDS card no 090432. It is well known that HA cell parameters are dependent on the synthesis method used [31].

\section{SEM, EDS and TEM Analysis}

SEM images of sample A1-A5 showed different morphologies for each $\mathrm{Ca} / \mathrm{Si}_{(\mathrm{R})}$ molar ratio (Fig. 3). For

Table 2. Cell parameters and crystallite size of HA in A0-A5 samples

\begin{tabular}{ccccc}
\hline Sample & $\mathrm{a}(\mathrm{nm})$ & $\mathrm{c}(\mathrm{nm})$ & $\mathrm{V}\left(\mathrm{nm}^{3}\right)$ & Crystallite size $(\mathrm{nm})$ \\
\hline A0 & $0.935 \pm 6.10^{-4}$ & $0.683 \pm 3.10^{-4}$ & $1.549 \pm 1.2 .10^{-3}$ & $12.788 \pm 0.450$ \\
A1 & $0.933 \pm 5.10^{-4}$ & $0.687 \pm 3.10^{-4}$ & $1.554 \pm 1.0 .10^{-3}$ & $7.557 \pm 0.164$ \\
$\mathrm{~A} 2$ & $0.935 \pm 5.10^{-4}$ & $0.688 \pm 3.10^{-4}$ & $1.561 \pm 0.9 .10^{-3}$ & $7.783 \pm 0.230$ \\
$\mathrm{~A} 3$ & $0.935 \pm 4.10^{-4}$ & $0.688 \pm 2.10^{-4}$ & $1.562 \pm 0.8 .10^{-3}$ & $8.413 \pm 0.126$ \\
$\mathrm{~A} 4$ & $0.937 \pm 4.10^{-4}$ & $0.689 \pm 2.10^{-4}$ & $1.572 \pm 0.8 .10^{-3}$ & $8.971 \pm 0.152$ \\
$\mathrm{~A} 5$ & $0.935 \pm 4.10^{-4}$ & $0.686 \pm 2.10^{-4}$ & $1.559 \pm 0.8 .10^{-3}$ & $9.581 \pm 0.144$ \\
\hline
\end{tabular}

Tri Windarti et al. 

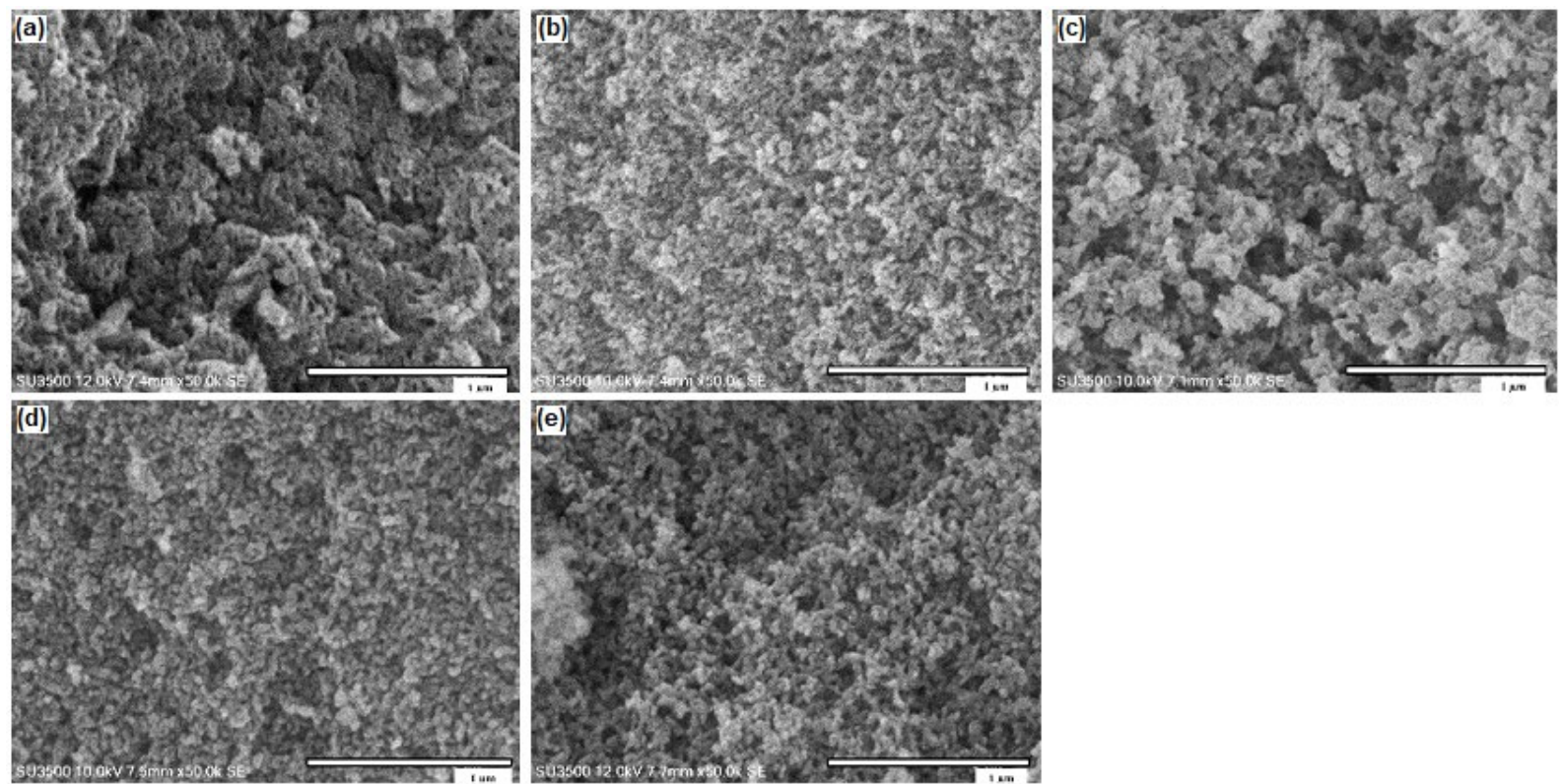

Fig 3. Surface topography of A1 (a), A2 (b), A3 (c), A4 (d), and A5 (e) sample

$\mathrm{Ca} / \mathrm{Si}_{(\mathrm{R})}=5$ (A1), the image showed a rough surface that compose of regular shape particles with size $<100 \mathrm{~nm}$. For $\mathrm{Ca} / \mathrm{Si}_{(\mathrm{R})}=10$ (A2), the surface morphology was flat with more tightly arranged particles. A different image was shown for $\mathrm{Ca} / \mathrm{Si}_{(\mathrm{R})}=15(\mathrm{~A} 3)$, where the particles were larger than $\mathrm{A} 1$ and $\mathrm{A} 2$, and agglomerated without a pattern. For $\mathrm{Ca} / \mathrm{Si}_{(\mathrm{R})}=20$ (A4) and 25 (A5), the images were nearly the same as $\mathrm{A} 2$, in which the particles have a regular shape with size $<100 \mathrm{~nm}$.

TEM images of samples A0, A1, and A5 showed that particles of pure $\mathrm{HA}$ were different in shape and size compared to $\mathrm{HA}-\mathrm{SiO}_{2}$ composite particles (Fig. 4). Pure HA particles were in the form of long rod-like shapes with particle size $<100 \mathrm{~nm}$. Particles of the $\mathrm{HA}-\mathrm{SiO}_{2}$ composite in sample A1 were regular-shaped in the form of rod-like particles but in smaller sizes $(<50 \mathrm{~nm})$. A different phenomenon occurred to sample A5, in which its shape and size were a combination of A0 and A1 samples. Short rod-like particles with particle sizes of $<50 \mathrm{~nm}$ were mixed with long rod-like particles with particle sizes of $<100 \mathrm{~nm}$. These images as well as the crystallite size data confirmed that $\mathrm{SiO}_{2}$ acted as a morphology directing agent. Through silanol - $\mathrm{Ca}$ interactions, the $\mathrm{Ca}_{9}\left(\mathrm{PO}_{4}\right)_{6}$ clusters were formed on the $\mathrm{SiO}_{2}$ surface, and then these intermediate states grew in 3 dimensions to build HA crystallite on the silica surface [30]. The other $\mathrm{HA}-\mathrm{SiO}_{2}$ clusters inhibited further growth of HA so that $\mathrm{HA}-\mathrm{SiO}_{2}$ composite with lower $\mathrm{Ca} / \mathrm{Si}$ ratio had smaller particles, hence suitable to be used as the powder component of CPC. The particles can produce a paste
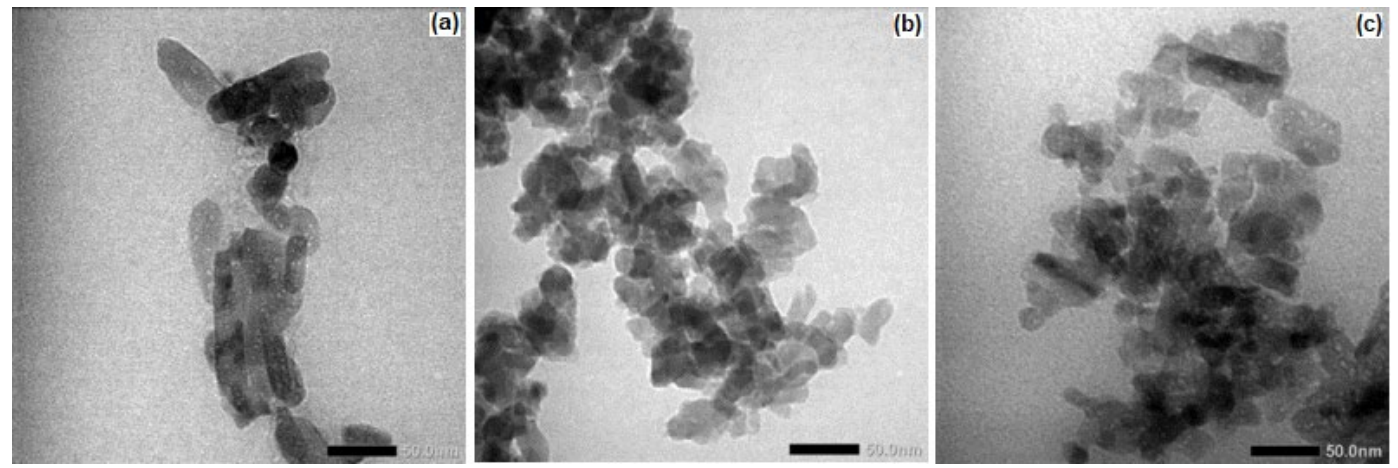

Fig 4. TEM images of A0 (a), A1 (b) and A5 (c) sample 
with high viscosity due to the low particle-particle and particle-syringe wall friction.

Table 3 shows the elemental composition of the surface of the HA-SiO2 composites. By increasing the $\mathrm{Ca} / \mathrm{Si}_{(\mathrm{R})}$ molar ratio, the Si content decreased from 2.72 to $0.54 \%$, while the P content tended to be stable at 11.81 $13.68 \%$. The O content increased from 61.92 to $68.98 \%$, while the Ca content fluctuated around 18.67-23.32\%. The $\mathrm{Ca} / \mathrm{Si}(\mathrm{p})$ ratio of the composites tended to increase linearly with $\mathrm{Ca} / \mathrm{Si} \mathrm{i}_{(\mathrm{R})}$, except for sample $\mathrm{A} 3$. Meanwhile, $\mathrm{Ca} / \mathrm{P}_{(\mathrm{p})}$ or $\mathrm{Ca} / \mathrm{P}$ ratio of the composites tended to decrease by the increase of $\mathrm{Ca} / \mathrm{Si}_{(\mathrm{R})}$, except for sample A4. This can happen due to the tendency of $\mathrm{HA}$ and $\mathrm{SiO}_{2}$ particles to agglomerate [23]. For all $\mathrm{Ca} / \mathrm{Si}(\mathrm{R})$ ratios except for $\mathrm{Ca} / \mathrm{Si}(\mathrm{R})$ $=15(\mathrm{~A} 3)$, the $\mathrm{Ca} / \mathrm{Si}_{(\mathrm{p})}$ was higher than $\mathrm{Ca} / \mathrm{Si}_{(\mathrm{R})}$ (Table 1$)$. This data confirmed that $\mathrm{SiO}_{2}$ tended to be in the inside of the $\mathrm{HA}-\mathrm{SiO}_{2}$ composite while $\mathrm{HA}$ covered the composite surface.

The formation of $\mathrm{HA}-\mathrm{SiO}_{2}$ composites with $\mathrm{HA}$ deposited on the $\mathrm{SiO}_{2}$ surface was confirmed with EDS element mapping (Fig. 5). Mapping was done for $\mathrm{Ca}, \mathrm{P}$, $\mathrm{Si}$, and $\mathrm{O}$ on the sample surface area of $750 \mu \mathrm{m}^{2}$. For
$\mathrm{Ca} / \mathrm{Si}_{(\mathrm{R})}$ of 5 (A1), the mapping of $\mathrm{Ca}$ and $\mathrm{P}$ showed that both elements were evenly distributed on the sample surface with the same color intensity. Both images showed dark holes in the same position. Si element mapping confirmed that the dark holes were $\mathrm{Si}$ aggregates and there were at least five Si aggregates. The absence of black holes in the element mapping of $\mathrm{O}$ indicated that the composite surface was filled with oxygen. The image for element $\mathrm{O}$ showed that the composite surface was rough. For $\mathrm{Ca} / \mathrm{Si}_{(\mathrm{R})}$ of 25 (A5), the element mapping of $\mathrm{Ca}$ and $\mathrm{P}$ was not as intense as for the A1 sample. The images showed two dark holes in the same position. Image mapping of Si confirmed that only 1 of the holes was Si aggregate and from image mapping of $\mathrm{O}$, the second hole indicated that the composite surface was rough. Besides appearing as an agglomerate, $\mathrm{Si}$ was also distributed evenly on the composite surface. At high $\mathrm{Ca} / \mathrm{Si}$ ratios, $\mathrm{Si}$ had a low tendency to form aggregates. The surface phenomenon of sample A5 was related to the element composition in Table 3 . The value of $\mathrm{Ca} / \mathrm{P}_{(\mathrm{P})}$ and $\mathrm{Ca} / \mathrm{Si}_{(\mathrm{P})}$ indicated that $\mathrm{HA}$ covered the composite surface. For CPC application, the presence of

Table 3. Elements composition, $\mathrm{Ca} / \mathrm{P}_{(\mathrm{P})}$ and $\mathrm{Ca} / \mathrm{Si} \mathrm{i}_{(\mathrm{P})}$ ratio on $\mathrm{HA}-\mathrm{SiO}_{2}$ composite surface

\begin{tabular}{|c|c|c|c|c|c|c|}
\hline \multirow{2}{*}{ Sample } & \multicolumn{4}{|c|}{ Element (\%) } & \multirow{2}{*}{$\begin{array}{c}\mathrm{Ca} / \mathrm{P}_{(\mathrm{P})} \\
\text { Ratio }\end{array}$} & \multirow{2}{*}{$\begin{array}{c}\mathrm{Ca} / \mathrm{Si}_{(\mathrm{P})} \\
\text { Ratio }\end{array}$} \\
\hline & $\mathrm{Ca}$ & $\mathrm{P}$ & $\mathrm{Si}$ & $\mathrm{O}$ & & \\
\hline A1 & 22.48 & 12.88 & 2.72 & 61.92 & 1.75 & 8.26 \\
\hline A2 & 22.59 & 13.68 & 1.33 & 62.40 & 1.65 & 16.98 \\
\hline A3 & 20.50 & 12.65 & 1.47 & 65.37 & 1.62 & 13.95 \\
\hline A4 & 23.32 & 12.22 & 0.76 & 63.70 & 1.91 & 30.68 \\
\hline A5 & 18.67 & 11.81 & 0.54 & 68.98 & 1.58 & 34.57 \\
\hline
\end{tabular}
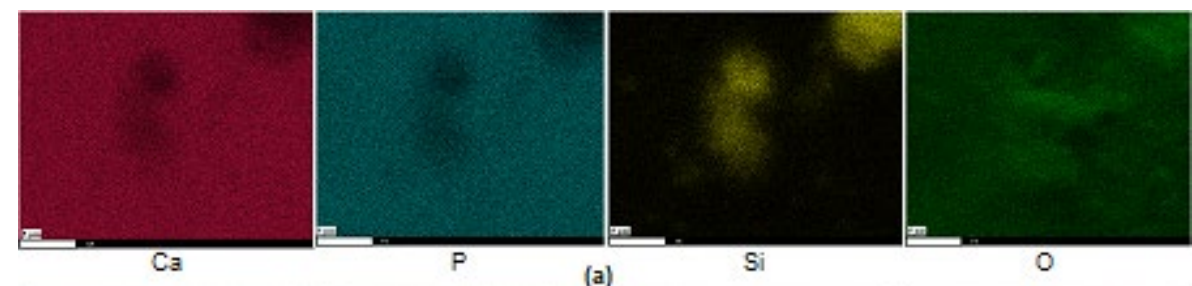

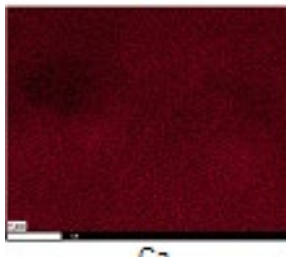

$\mathrm{Ca}$

Fig 5. Surface element mapping of A1 (a) and A5 (b) sample 
Table 4. The zeta potential of $\mathrm{SiO}_{2}$ and $\mathrm{A} 0-\mathrm{A} 5$ samples

\begin{tabular}{cc}
\hline Sample & Zeta Potential $(\mathrm{mV})$ \\
\hline $\mathrm{SiO}_{2}$ & $-43.895 \pm 0.061$ \\
$\mathrm{~A} 0$ & $-1.623 \pm 0.025$ \\
$\mathrm{~A} 1$ & $-1.759 \pm 0.028$ \\
$\mathrm{~A} 2$ & $-0.259 \pm 0.027$ \\
$\mathrm{~A} 3$ & $-1.481 \pm 0.027$ \\
$\mathrm{~A} 4$ & $-1.411 \pm 0.057$ \\
$\mathrm{~A} 5$ & $-2.935 \pm 0.030$ \\
\hline
\end{tabular}

HA on the composite surface is highly expected due to the HA ability to interact with living bone tissues [1-3]. In addition, the rough surface of the composite will support the attachment of CPC on the bone tissue surface [31].

\section{Measurement of Zeta Potential}

Table 4 shows the zeta potential of $\mathrm{SiO}_{2}$ and $\mathrm{A} 0-\mathrm{A} 5$ samples in water. The zeta potential value of $\mathrm{SiO}_{2}$ was $-43.895 \pm 0.061 \mathrm{mV}$, which indicated that the $\mathrm{SiO}_{2}$ dispersion in water was stable. In contrast, a previous study found that silica nanoparticles made from Bambusa vulgaris leaves had a zeta potential value of $-0.29 \mathrm{mV}$ [32]. Sample A1 that contained pure HA had a zeta potential of $-1.623 \pm 0.025 \mathrm{mV}$, which indicated that HA dispersion in water was unstable and had a great tendency to form aggregates quickly. The same condition occurred to samples A1-A5. The zeta potential of $\mathrm{HA}-\mathrm{SiO}_{2}$ composites was about $-0.259 \pm 0.027$ to $-2.935 \pm 0.030 \mathrm{mV}$. The stability of $\mathrm{SiO}_{2}$ dispersion changed due to the deposition of HA. HA that was deposited on the $\mathrm{SiO}_{2}$ surface decreased the repulsion energy of the particles in water. The negative zeta potential value of the $\mathrm{HA}-\mathrm{SiO}_{2}$ composite will be beneficial to CPC because it will drive $\mathrm{Ca}^{2+}$ ions in the body liquid to attach to the CPC surface. Furthermore, a negative zeta potential value is required in bone cell adhesion [26]. Therefore, the composite is predicted to have good bioactivity [33].

\section{- CONCLUSION}

The obtained $\mathrm{HA}-\mathrm{SiO}_{2}$ composite had excellent properties such as being covered by HA, resulting in greater lattice volume and smaller crystallite size compared to pure $\mathrm{HA}$. The shape of the $\mathrm{HA}-\mathrm{SiO}_{2}$ particles was similar to pure $\mathrm{HA}$ but smaller in size. The composites surface was rough with zeta potential values almost the same as pure HA. These properties make HA$\mathrm{SiO}_{2}$ composite a promising material to be used as a powder component of injectable calcium phosphate cement.

\section{- ACKNOWLEDGMENTS}

The authors gratefully acknowledge Universitas Gadjah Mada, Yogyakarta, Indonesia for the financial support through the research grant "Rekognisi Tugas Akhir (RTA)" with the contract number: 3204/UN1/DITLIT/DIT-LIT/LT/2019.

\section{- AUTHOR CONTRIBUTIONS}

Tri Windarti carried out the experiment, Tri Windarti and Nuryono analyzed data and wrote the manuscript, Nuryono and Widjijono supervised the experiment. All authors approved the manuscript.

\section{- REFERENCES}

[1] Larsson, S., Stadelmann, V.A., Arnoldi, J., Behrens, M., Hess, B., Procter, P., Murphy, M., and Pioletti, D.P., 2012, Injectable calcium phosphate cement for augmentation around cancellous bone screws. In vivo biomechanical studies, J. Biomech., 45 (7), 1156-1160.

[2] Apelt, D., Theiss, F., El-Warrak, A.O., Zlinszky, K., Bettschart-Wolfisberger, R., Bohner, M., Matter, S., Auer, J.A., and von Rechenberg, B., 2004, In vivo behavior of three different injectable hydraulic calcium phosphate cements, Biomaterials, 25 (7-8), 1439-1451.

[3] Heinemann, S., Rössler, S., Lemm, M., Ruhnow, M., and Nies, B., 2013, Properties of injectable ready-touse calcium phosphate cement based on waterimmiscible liquid, Acta Biomater., 9 (4), 6199-6207.

[4] Motisuke, M., Mestres, G., Renó, C.O., Carrodeguas, R.G., Zavaglia, C.A.C., and Ginebra, M.P., 2017, Influence of Si substitution on the reactivity of a-tricalcium phosphate, Mater. Sci. Eng., C, 75, 816-821.

[5] Zhou, S., Ma, J., Shen, Y., Haapasalo, M., Ruse, N.D., Yang, Q., and Troczynski, T., 2013, In vitro 
studies of calcium phosphate silicate bone cements, J. Mater. Sci. Mater. Med., 24 (2), 355-364.

[6] Sowjanya, J.A., Singh, J., Mohita, T., Sarvanan, S., Moorthi, A., Srinivasan, N., and Selvamurugan, N., 2013, Biocomposite scaffolds containing chitosan/ alginate/nano-silica for bone tissue engineering, Colloids Surf., B, 109, 294-300.

[7] Sopcak, T., Medvecky, L., Giretova, M., Stulajterova, R., Durisin, J., Girman, V., and Faberova, M., 2016, Effect of phase composition of calcium silicate phosphate component on properties of brushite based composite cements, Mater. Charact., 117, 17-29.

[8] Heinemann, S., Heinemann, C., Wenisch, S., Alt, V., Worch, H., and Hanke, T., 2013, Calcium phosphate phases integrated in silica/collagen nanocomposite xerogels enhance the bioactivity and ultimately manipulate the osteoblast/osteoclast ratio in a human co-culture model, Acta Biomater., 9 (1), 4878-4888.

[9] Szurkowska, K., and Kolmas, J., 2017, Hydroxyapatites enriched in silicon-Bioceramic materials for biomedical and pharmaceutical applications, Prog. Nat. Sci., 27 (4), 401-409.

[10] Motisuke, M., Santos, V.R., Bazanini, N.C., and Bertran, C.A., 2014, Apatite bone cement reinforced with calcium silicate fibers, J. Mater. Sci. Mater. Med., 25 (10), 2357-2363.

[11] Geffers, M., Barralet, J.E., Groll, J., and Gbureck, U., 2015, Dual-setting brushite-silica gel cements, Acta Biomater., 11, 467-476.

[12] Ahn, G., Lee, J.Y., Seol, D.W., Pyo, S.G., and Lee, D., 2013, The effect of calcium phosphate cement-silica composite materials on proliferation and differentiation of pre-osteoblast cells, Mater. Lett., 109, 302-305.

[13] Kao, C.T., Huang, T.H., Chen, Y.J., Hung, C.J., Lin, C.C., and Shie, M.Y., 2014, Using calcium silicate to regulate the physicochemical and biological properties when using $\beta$-tricalcium phosphate as bone cement, Mater. Sci. Eng., C, 43, 126-134.

[14] Tomoaia, G., Mocanu, A., Vida-Simiti, I., Jumate, N., Bobos, L.D., Soritau, O., and Tomoaia-Cotisel, M., 2014, Silicon effect on the composition and structure of nanocalcium phosphates: In vitro biocompatibility to human osteoblasts, Mater. Sci. Eng., C, 37, 37-47.

[15] Song, Z., Liu, Y., Shi, J., Ma, T., Zhang, Z., Ma, H., and Cao, S., 2018, Hydroxyapatite/mesoporous silica coated gold nanorods with improved degradability as a multi-responsive drug delivery platform, Mater. Sci. Eng., C, 83, 90-98.

[16] Grandfield, K., and Zhitomirsky, I., 2008, Electrophoretic deposition of composite hydroxyapatite-silica-chitosan coatings, Mater. Charact., 59 (1), 61-67.

[17] Jia, Z.Q., Guo, Z.X., Chen, F., Li, J.J., Zhao, L., and Zhang, L., 2018, Microstructure, phase compositions and in vitro evaluation of freeze casting hydroxyapatite-silica scaffolds, Ceram. Int., 44 (4), 3636-3643.

[18] Villacampa, A.I., and García-Ruiz, J.M., 2000, Synthesis of a new hydroxyapatite-silica composite material, J. Cryst. Growth, 211 (1-4), 111-115.

[19] Karimi, R., Abbas, A., Nourbakhsh, N., Nourbakhsh, M., and Mackenzie, K.J.D., 2017, Phase formation, microstructure and setting time of MCM-48 mesoporous silica nanocomposites with hydroxyapatite for dental applications: Effect of the $\mathrm{Ca} / \mathrm{P}$ ratio, Ceram. Int., 43 (15), 12857-12862.

[20] Yamada, S., Nishikawa, M., and Tagaya, M., 2018, Mesoporous silica formation on hydroxyapatite nanoparticles, Mater. Lett., 211, 220-224.

[21] Shen, Y., 2017, Rice husk silica derived nanomaterials for sustainable applications, Renewable Sustainable Energy Rev., 80, 453-466.

[22] Pode, R., 2016, Potential applications of rice husk ash waste from rice husk biomass power plant, Renewable Sustainable Energy Rev., 53, 1468-1485.

[23] Yousefpour, M., and Taherian, Z., 2013, The effects of ageing time on the microstructure and properties of mesoporous silica-hydroxyapatite nanocomposite, Superlattices Microstruct., 54, 78-86.

[24] Nayak, J., and Bera, J., 2009, A simple method for production of humidity indicating silica gel from rice husk ash, J. Met. Mater. Miner., 19 (2), 15-19.

[25] Pajchel, L., and Kolodziejski, W., 2018, Synthesis and characterization of MCM-48/hydroxyapatite 
composites for drug delivery: Ibuprofen incorporation, location and release studies, Mater. Sci. Eng., C, 91, 734-742.

[26] Fahami, A., Beall, G.W., and Betancourt, T., 2016, Synthesis, bioactivity and zeta potential investigations of chlorine and fluorine substituted hydroxyapatite, Mater. Sci. Eng., C, 59, 78-85.

[27] Malakauskaite-Petruleviciene, M., Stankeviciute, Z., Niaura, G., and Garskaite, E., 2016, Characterization of sol-gel processing of calcium phosphate thin films on silicon substrate by FTIR spectroscopy, Vib. Spectrosc., 85, 16-21.

[28] Nurlidar, F., and Kobayashi, M., 2019, Succinylated bacterial cellulose induce carbonated hydroxyapatite deposition in a solution mimicking body fluid, Indones. J. Chem., 19 (4), 858-864.

[29] Hamzah, S., Yatim, N.I., Alias, M., Ali, A., Rasit, N., and Abuhabib, A., 2019, Extraction of hydroxyapatite from fish scales and its integration with rice husk for ammonia removal in aquaculture wastewater, Indones. J. Chem., 19 (4), 1019-1030.
[30] Shiba, K., Motozuka, S., Yamaguchi, T., Ogawa, N., Otsuka, Y., Ohnuma, K., Kataoka, T., and Tagaya, M., 2015, Effect of cationic surfactant micelles on hydroxyapatite nanocrystal formation: An investigation into the inorganic-organic interfacial interactions, Cryst. Growth Des., 16 (3), 1463-1471.

[31] Dorozhkin, S.V., 2017, "Calcium orthophosphatebased bioceramis and its clinical applications" in Clinical Applications of Biomaterials, Eds. Kaur, G., Springer International, Switzerland, 123-226.

[32] Durairaj, K., Senthilkumar, P., Velmurugan, P., Dhamodaran, K., Kadirvelu, K., and Kumaran, S., 2019, Sol-gel mediated synthesis of silica nanoparticle from Bambusa vulgaris leaves and its environmental applications: Kinetics and isotherms studies, J. Sol-Gel Sci. Technol., 90 (3), 653-664.

[33] Latifi, S.M., Fathi, M., Sharifnabi, A., and Varshosaz, J., 2017, In vitro characterisation of a sol-gel derived in situ silica-coated silicate and carbonate co-doped hydroxyapatite nanopowder for bone grafting, Mater. Sci. Eng., C, 75, 272-278. 